\title{
Angiogenesis, Metabolism, Endothelial And Platelet Markers In Diabetes And Cardiovascular Disease
}

\author{
AD Blann ( $\square$ a.blann@hud.ac.uk) \\ Huddersfield University \\ JE Brown \\ Aston University \\ R Heitmar \\ Huddersfield University
}

\section{Research Article}

Keywords: diabetes, cardiovascular disease, angiogenesis, endothelium, platelets, renal function

Posted Date: November 19th, 2021

DOI: https://doi.org/10.21203/rs.3.rs-1087225/v1

License: (1) This work is licensed under a Creative Commons Attribution 4.0 International License.

Read Full License

Version of Record: A version of this preprint was published at British Journal of Biomedical Science on March 22nd, 2022. See the published version at https://doi.org/10.3389/bjbs.2022.10313. 


\section{Abstract}

Introduction: Diabetes is a leading risk factor for cardiovascular disease (CVD), the pathophysiology of both being linked to metabolic, endothelial, renal, angiogenic and platelet abnormalities. We hypothesised that abnormalities in these systems are more adverse in those whose CVD is compounded by diabetes, compared to those with diabetes or CVD alone.

Materials and methods: Serum or plasma from 66 patients with diabetes alone, 76 with CVD alone, and 70 with both diabetes and CVD i.e. diabetic cardiovascular disease, was probed for markers of angiogenesis [angiopoietin 1 and 2, vascular endothelial growth factor (VEGF) and endoglin], metabolic [sRAGE, leptin, lipocalin-2, interleukin-8, and cystatin-C], the endothelium (von Willebrand factor, endothelial microparticles and soluble E selectin]), and the platelet (platelet microparticles and soluble P selectin) by ELISA, Luminex or flow cytometry.

Results: VEGF ( $p=0.04)$, von Willebrand factor $(p=0.001)$ and endothelial microparticles $(p=0.042)$ were all higher in diabetic cardiovascular disease than in diabetes alone and cardiovascular disease alone. Soluble E selectin was higher in diabetic cardiovascular disease than in diabetes alone $(p=0.045)$, whilst cystatin-C $(p=0.004)$ and soluble P selectin $(p<0.001)$ were higher in diabetes and diabetic cardiovascular disease than in cardiovascular disease alone. There were no differences in angiopoietin 1 or 2, endoglin, sRAGE, leptin, lipocalin-2, or interleukin-8.

Conclusion: Angiopoietin 1 or 2, endoglin, sRAGE, leptin, lipocalin-2, interleukin-8, and cystatin-c cannot differentiate diabetes from cardiovascular disease, or both conditions combined. Our data point to a more adverse endothelial (von Willebrand factor, endothelial microparticles), and angiogenic profile (VEGF) in those with diabetic cardiovascular disease, supporting the view that this group should be targeted more aggressively.

\section{Introduction}

Cardiovascular disease (CVD) has a complex pathogenesis and can manifest as coronary artery disease (such as previous myocardial infarction and coronary artery stenosis/occlusion), heart failure, cerebrovascular disease (leading to stroke) and peripheral artery disease (often requiring amputation). Diabetes is a major risk factor for CVD, but many diabetics also have other risk factors and other pathology such as retinopathy, obesity, hypertension, and renal disease, several of which are also present in CVD $[1,2]$. From a perspective of clinical practice, CVD, where by definition a major event has already occurred and/or is present, requires more complex and urgent management, often focussing on risk factors and signs/symptoms. The pathophysiology of CVD and diabetes involves many different disease processes, such as inflammation and those acting on the endothelium and the platelet, adverse changes to both potentially leading to thrombosis and hypertension, and a developing theme in both is inappropriate angiogenesis $[3,4]$. 
Abnormalities in several other metabolic processes are evident in these diseases, and may be marked by molecular markers such as SRAGE (soluble receptor for advanced glycation end-products, arising from the endothelium and elsewhere, and with pathophysiological links to diabetes), cystatin-c (reflecting renal function), leptin (arising from adipose tissue and with roles in digestion), lipocalin-2 (an inflammatory adipokine, also known as neutrophil gelatinase-associated lipocalin, linked to nephropathy) and interleukin-8 (also known as CXCL8, a pro-inflammatory cytokine) (5-9). Leading soluble markers of angiogenesis include vascular endothelial growth factor (VEGF), angiopoietins 1 and 2 (Ang-1, Ang-2) and endoglin (CD105)(10-12), whilst pathophysiology of the endothelium may be marked by von Willebrand factor (vWf), soluble E-selectin (sEsel) and by endothelial microparticles (EMPs)(13-16). Changes in platelet pathophysiology may be reflected by altered soluble P-selectin and platelet microparticles $(16,17)$.

Despite these abnormalities, diabetes and CVD without diabetes are often viewed as having a similar pathogenicity with (if un- or poorly treated) equivalent likelihoods of disease progression. However, the strength of certain of these pathogenic processes in the presence of both disease processes, and their combination, is unclear. We therefore hypothesised that those patients with both conditions would, despite appropriate clinical care, have a more adverse marker profile than those with either disease alone.

\section{Materials And Methods}

We tested our hypothesis in 212 age and sex-matched patients with an established history of diabetes $(n=66), C V D(n=76)$, or both conditions $(n=70)$ recruited from Out-patients attending City Hospital, Birmingham, UK (a University Teaching Hospital). Inclusion criteria were type 2 diabetics attending a diabetes clinic, and patients with atherosclerotic coronary artery disease attending a cardiology clinic. Exclusion criteria were age $<18$ years, present or history of cancer, lone atrial fibrillation, lone heart failure, other endocrine or metabolic disease, and any inflammatory disease such as thyroiditis or rheumatoid arthritis. The study had the approval of the local research ethics committee and informed written consent was obtained from all participants in accordance with the Declaration of Helsinki.

Each participant provided blood samples for routine biochemistry analyses. Markers of renal function and $\mathrm{HbA1c}$ were measured by standard routine methods. Blood pressure was measured by an Omron M3 digital sphygmomanometer. Research indices Ang-1, Ang-2, interleukin-8, sRAGE, Cystatin C, leptin, lipocalin, endoglin and VEGF, and routine marker C-reactive protein (CRP) were analysed using MAGPIX Luminex assays (Merck Millipore, Burlington, Mass, USA) that uses a miniaturised liquid array immunoassay with colour-coded magnetic microspheres. Briefly, $20 \mu$ samples of diluted (1/5) plasma were analysed using XMAP Luminex technology and xPONENT software (Luminex, Austin, Texas, USA). vWf, sEsel and sPel were determined by ELISA using commercial reagents (Dako, Ely, UK and R\&D Systems, Abingdon UK). PMPs and EMPs were measured by fluoresence flow cytometry using monoclonal antibodies to CD42b and CD144 respectively (Abcam, Cambridge, UK) as described elsewhere $(18,19)$. 
Continuously variable data are presented as mean with standard deviation or median with interquartile range and analysed by analysis of variance or the Kruskal-Wallis test as distribution demands.

Categorical data is presented as number and percentage and analysed by the chi-squared test.

Differences between groups were sought by Tukey's post-hoc test. Those indices significantly different in univariate analyses were further analysed by multivariate logistic regression. Correlations were sought using Spearman's method. $\mathrm{P}<0.05$ was considered significant, analyses were performed on Minitab 19.

\section{Results}

Table 1 shows standard clinical, laboratory and demographic data on the three groups, matched for age and sex, many of which are as expected, such as increased BMI and HbA1c in diabetes. Diastolic blood pressure was lower in those with both diseases compared with either alone, perhaps linked to the greater use of anti-hypertensive agents. Although creatinine was higher in those with any diabetes, the eGFR was no different, perhaps reflecting age, sex, and racial profile of the groups. Greater use of statins in those with any CVD most likely reflects guidance from the UK's National Institute for Health and Care Excellence (20), leading documents regarding clinical practice. Notable, the median and upper quartile CRP in each group was less than the local reference range of $<5 \mathrm{mg} / \mathrm{L}$

Table 2 shows research markers. Levels of VEGF, but not other markers of angiogenesis, were higher in those with both diabetes and CVD compared to those with diabetes alone $(p=0.012)$. Levels of endoglin correlated weakly with those of angiopoietin- $1(r=0.21, p=0.007)$. In multivariate logistic regression only VEGF remained an independent predictor of the presence of diabetes and CVD. Of the metabolic markers, only cystatin-C differed between the groups, being higher in diabetes plus CVD than in CVD alone (both $p=0.001)$. Overall, levels of cystatin- $C$ correlated modestly with those of creatinine $(r=0.45, p<0.001)$ and eGFR $(r=-0.49 p<0.001)$. In logistic regression, both creatinine $(p=0.034)$ and cystatin- $C(p=0.009)$ were independent predictors of CVD versus diabetes plus CVD. Overall, leptin correlated modestly with HbA1C $(r=0.31, p=0.02)$ and $B M I(r=0.45, p<0.001)$.

There were several differences in endothelial and platelet markers. vWf and EMPs were both higher in diabetes plus CVD compared to diabetes alone ( $p=0.001$ and $p=0.045$ respectively) and in diabetes plus CVD versus CVD alone ( $p=0.007$ and $p=0.02$, respectively. However, these two markers failed to correlate significantly $(r=0.04, p=0.53)$. sEsel was higher in CVD alone $(p=0.038)$ and in diabetes plus CVD $(p=0.027)$ compared to diabetes alone. In logistic regression, both $\mathrm{vWf}(p<0.001)$ and EMPs $(p=0.029)$ were significant independent predictors of group. There was no overall difference in PMPs, but levels of sPsel were higher in diabetes alone $(p<0.001)$ and in diabetes plus CVD $(p=0.001)$ compared to CVD alone.

\section{Discussion}

Diabetes is perhaps the leading risk factor for CVD, and accordingly requires focussed management to clinically-relevant targets (20-22), whilst the importance of concurrent diabetes and CVD is also becoming 
recognised $(23,24)$. Although intensive blood glucose control reduces the risk of myocardial infarction, it does not reduce all-cause or cardiovascular mortality (25), implying other measures targeting alternative risk factors/pathology are required.

We tested the hypothesis that patients with CVD compounded by diabetes would have more adverse metabolic, angiogenic, endothelial, platelet and renal profiles than those with either disease in isolation. Of the markers of angiogenesis, VEGF was marginally higher in those with diabetes and CVD. Neri et al have argued that increased VEGF in diabetes reflects subclinical endothelial dysfunction (26), whilst others suggest it is the consequence of hypoxia $(27,28)$. Raised VEGF in our patients may be a marker of early diabetic retinopathy $(29,30)$, although this clinical feature was not recorded. Increased levels of this growth factor are widely regarded as reflective of aberrant angiogenesis and as possible markers of endothelial pathology (26-30). Angiopoietins 1 and 2 may also have a role in diabetic retinopathy $(31,32)$, and increased levels of these molecules have been described acute myocardial infarction (33). A report of similar design to ours with diabetes and unstable angina pectoris (UAP) found no changes in angiogenic factors in diabetes alone, but increased VEGF and angiopoietin-2 in UAP. Sub-group analysis of the latter according to diabetes failed to find differences in any angiogenic markers, whereas we report increased VEGF in diabetes plus CVD compared to CVD alone, perhaps as our study has around twice the statistical power (34). Increased levels of endoglin may have a role in diabetic retinopathy, hypertension, and the metabolic syndrome (35-37), but in our hands it could not differentiate any of the diabetes and CVD groups. Although described as an endothelial product $(38,39)$, levels failed to correlate with any established markers of this cell.

Of the metabolic markers, only cystatin-C differed between the groups, being highest in both diabetes groups, and correlating overall with renal markers. We speculate that it may have an as yet unspecified role in these conditions, perhaps linked to renal function. Notably, in a prospective study, high levels of cystatin-C brought a hazard ratio of 1.66 for CVD death (40). Although leptin failed to differ between the groups, in the entire cohort it correlated strongly with BMI, possibly reflecting its adipocyte origin, but less convincingly with $\mathrm{HbA1c}$. Whilst a precise pathophysiological role(s) for this molecular is unclear, increased levels predict prognosis in established coronary atherosclerosis, even when adjusting for BMI (41).

All endothelial markers differed between the groups, the largest being in vWf, where levels were some $10 \%$ higher in diabetes plus CVD, supporting the broad hypothesis of increased vascular damage in the face of multiple risk factors $(42,43)$. Although the relative increase in EMPs $(\sim 70 \%)$ was considerably higher than that of vWf, a greater variance brought only marginal significance. Nevertheless, increased EMPs are likely to have some pathological significance independent of vWf as the two failed to correlate. sPsel levels again tracked both diabetes groups, an observation that cannot be ascribed to the increased use of aspirin (known to reduce sPsel (44)) in our patients with CVD. This is in contrast to a previous report (45) which found no difference in sPsel in diabetes compared to diabetes plus CVD, although an improvement is risk factor profiles with intensive treatment in diabetics alone resulted in reduced levels. 
We acknowledge the limitation of a modest sample size, but consider a strength to be the real world nature of the patients managed in secondary care. Furthermore, the three groups are matched for CRP, and as levels are low the changes we report cannot be reflective of sub-clinical or laboratory defined inflammation.

\section{Conclusion}

Our data supports the hypothesis that diabetes plus CVD brings a more adverse plasma marker profile than neither group alone. Indeed, levels of 8 of the 14 circulating research markers were highest in this combined group, despite apparent best clinical practice. If correct, this group is at highest risk of an adverse major cardiovascular event and so should be managed more aggressively.

\section{Abbreviations}

$\begin{array}{ll}\text { Ang-1 } & \text { Angiopoietin-1 } \\ \text { Ang-2 } & \text { Angiopoietin-2 } \\ \text { BMI } & \text { Body mass index } \\ \text { CRP } & \text { C-reactive protein } \\ \text { CVD } & \text { Cardiovascular disease } \\ \text { eGFR } & \text { Estimated glomerular filtration rate } \\ \text { ELISA } & \text { Enzyme linked immunosorbent assay } \\ \text { EMPs } & \text { Endothelial microparticles } \\ \text { HbA1c } & \text { Glycated haemoglobin } \\ \text { PMPs } & \text { Platelet microparticles } \\ \text { sEsel } & \text { Soluble E selectin } \\ \text { sPsel } & \text { Soluble P selectin } \\ \text { sRAGE } & \text { soluble receptor for advanced glycation end-products } \\ \text { VEGF } & \text { Vascular endothelial growth factor } \\ \text { vWf } & \text { von Willebrand factor }\end{array}$

\section{Declarations}


- The study had the approval of the local research ethics committee, and informed written consent was obtained from all participants in accord with the Declaration of Helsinki

- All authors give consent to publish

- Data is freely available on application

- There are no competing interests

- This research was supported by a "Hans and Gertrude Hirsch Small Grant" from Fight for Sight UK to Drs Heitmar and Blann.

- Drs Blann and Heitmar recruited the patients, Drs Blann and Brown performed the laboratory analyses, Dr Blann performed the statistical analysis, and all authors contributed to the writing of the manuscript.

- We are grateful to our colleagues Drs De, Lee, Lip, Ryder, and Varma for their co-operation in recruitment.

\section{References}

1. Poznyak A, Grechko AV, Poggio P, Myasoedova VA, Alfieri V, Orekhov AN. The diabetes mellitusatherosclerosis connection: The role of lipid and glucose metabolism. Int J Mol Sci. 2020;21:1835. doi: 10.3390/ijms21051835.

2. Barr AJ. The biochemical basis of disease. Essays Biochem 2018:62;619-642.

3. Theodorou K, Boon RA. Endothelial Cell Metabolism in Atherosclerosis. Front Cell Dev Biol. 2018;6:82. doi: $10.3389 /$ fcell.2018.00082

4. Eelen G, de Zeeuw P, Simons M, Carmeliet P. Endothelial cell metabolism in normal and diseased vasculature. Circ Res. 2015;116:1231-44.

5. Steenbeke M, De Bruyne S, De Buyzere M et al. The role of soluble receptor for advanced glycation endproducts (SRAGE) in the general population and patients with diabetes mellitus with a focus on renal function and overall outcome. Crit Rev Clin Lab Sci. 2021 ;58:113-130.

6. Wu H, Du Q, Dai Q et al. Cysteine protease cathepsins in atherosclerotic cardiovascular diseases. J Atheroscler Thromb 2018:25;111-123.

7. Kang KW, Ok M, Lee SK. Leptin as a key between obesity and cardiovascular disease. J Obesity Metabol Syndrome 2020:29;248-259.

8. Helanova K, Spinar J, Parenica J. Diagnostic and prognostic utility of neutrophil gelatinase-associated lipocalin (NGAL) in patients with cardiovascular diseases. Kidney Blood Press Res 2014;39:623-9.

9. Gustafson B. Adipose tissue, inflammation, and atherosclerosis. J Atheroscler Thromb 2010;17:332341. 
10. Uccelli A, Wolff T, Valente $P$ et al. Vascular endothelial growth factor biology for regenerative angiogenesis. Swiss Med Wkly. 2019;149:w20011. doi: 10.4414/smw.2019.20011

11. Parikh SM. Angiopoietins and Tie2 in vascular inflammation. Curr Opin Hematol. 2017;24:432-438.

12. Kapur NK, Morine KJ, Letarte M. Endoglin: a critical mediator of cardiovascular health. Vasc Health Risk Manag. 2013;9:195-206.

13. Xiang Y, Hwa J. Regulation of VWF expression and secretion in health and disease. Curr Opin Hematol. 2016;23:288-93.

14. van der Leeuw J, Beulens JW, van Dieren S. Novel Biomarkers to Improve the Prediction of Cardiovascular Event Risk in Type 2 Diabetes Mellitus. J Am Heart Assoc. 2016;5:e003048.

15. Takahashi T, Kubo H. The role of microparticles in chronic obstructive pulmonary disease. Int $\mathrm{J}$ Chron Obstruct Pulmon Dis. 2014;9:303-14.

16. Voukalis C, Shantsila E, Lip GYH. Microparticles and cardiovascular diseases. Ann Med. 2019;51:193223.

17. Chen WS, Chen SJ, Lee CC et al. Plasma P-selectin predicts long-term cardiovascular events in hospitalized patients with suspected coronary artery disease and preserved left ventricular function: a 10year follow-up study. Biomed J. 2013;36:137-43.

18. Lau YC, Xiong Q, Blann AD, LIP GYH. Relationship between renal function and circulating microparticles, soluble P-selectin and E-selectin levels in atrial fibrillation. J Thromb Thrombolysis 2017;43:18-23.

19. Shantsila E, Wrigley B, Shantsila A, et al. Ethnic differences in macrovascular and microvascular function in systolic heart failure. Circ Heart Fail 2011;4:754-62.

20. National Institute for Health and Care Excellence, UK (www.nice.org.uk). CG147, CG181, QS100, NG17, and NG28.

21. Sillars A, Sattar N. Management of Lipid Abnormalities in Patients with Diabetes. Curr Cardiol Rep. 2019;21:147. doi: 10.1007/s11886-019-1246-1.

22. Apovian CM, Okemah J, O'Neil PM. Body Weight Considerations in the Management of Type 2 Diabetes. Adv Ther. 2019;36:44-58.

23. Bashier A, Bin Hussain A, Abdelgadir E et al. Consensus recommendations for management of patients with type 2 diabetes mellitus and cardiovascular diseases. Diabetol Metab Syndr. 2019;11:80. doi: 10.1186/s13098-019-0476-0. 
24. Mancini GBJ, Cheng AY, Connelly K et al. CardioDiabetes: Core Competencies for Cardiovascular Clinicians in a Rapidly Evolving Era of Type 2 Diabetes Management. Can J Cardiol. 2018;34:1350-1361. doi: 10.1016/j.cjca.2018.07.010

25. F M Turnbull, C Abraira, R J Anderson et al. Intensive glucose control and macrovascular outcomes in type 2 diabetes. Diabetologia 2009;52:2288-98.

26. Néri AK, da S Junior GB, Meneses GC et al. Cardiovascular risk assessment and association with novel biomarkers in patients with Type 2 diabetes mellitus. Biomark Med. 2021;15:561-576

27. Rossino MG, Lulli M, Amato R et al. Oxidative Stress Induces a VEGF Autocrine Loop in the Retina: Relevance for Diabetic Retinopathy. Cells. 2020;9:1452. doi: 10.3390/cells9061452

28. Qiu X, Wang X, Hong P et al. Retinal blood oxygen saturation and vascular endothelial growth factor-A in early diabetic retinopathy: A protocol for systematic review and meta-analysis. Medicine. 2020;99:e20562. doi: 10.1097

29. Ahuja S, Saxena S, Akduman L et al. Serum vascular endothelial growth factor is a biomolecular biomarker of severity of diabetic retinopathy. J Retina Vitreous. 2019;5:29. doi: 10.1186/

30. Gerhardinger C, Brown LF, Roy S et al. Expression of vascular endothelial growth factor in the human retina and in nonproliferative diabetic retinopathy. Am J Pathol. 1998;152:1453-62.

31. You QY, Zhuge FY, Zhu QQ et al. Effects of laser photocoagulation on serum angiopoietin-1, angiopoietin-2, angiopoietin-1/angiopoietin-2 ratio and soluble angiopoietin receptor Tie-2 in type 2 diabetic patients with proliferative retinopathy. Int J Ophthalmol 2014:7;648-53.

32. Lip PL, Chatterjee S, Caine GJ et al. Plasma vascular endothelial growth factor, angiopoietin-2, and soluble angiopoietin receptor tie-2 in diabetic retinopathy: effects of laser photocoagulation and angiotensin receptor blockade. $\mathrm{Br} \mathrm{J}$ Ophthalmol. 2004;88:1543-6.

33. Iribarren C, Phelps BH, Darbinian JA et al. Circulating angiopoietins-1 and -2, angiopoietin receptor Tie2 and vascular endothelial growth factor-A as biomarkers of acute myocardial infarction: a prospective nested case-control study. BMC Cardiovasc Disord. 2011 ;11:31. doi: 10.1186/1471-2261-11-31.

34. Gui C, Li SK, Nong QL et al. Changes of serum angiogenic factors concentrations in patients with diabetes and unstable angina pectoris. Cardiovasc Diabetol. 2013;12:34. doi: 10.1186/1475-2840$12-34$

35. Malik RA, Li C, Aziz W et al. Elevated plasma CD105 and vitreous VEGF levels in diabetic retinopathy. J Cell Mol Med. 2005;9:692-7

36. Blázquez-Medela AM, García-Ortiz L, Gómez-Marcos MA. Increased plasma soluble endoglin levels as an indicator of cardiovascular alterations in hypertensive and diabetic patients. BMC Med. 2010;8:86. doi: 
37. Vicen M, Igreja Sá IC, Tripská $\mathrm{K}$ et al. Membrane and soluble endoglin role in cardiovascular and metabolic disorders related to metabolic syndrome. Cell Mol Life Sci. 2021;78:2405-2418.

38. Leite AR, Borges-Canha M, Cardoso R et al. Novel Biomarkers for Evaluation of Endothelial Dysfunction. Angiology. 2020;71:397-410

39. Wallentin L, Eriksson N, Olszowka M et al. Plasma proteins associated with cardiovascular death in patients with chronic coronary heart disease: A retrospective study. PLoS Med. 2021;18:e1003513.

40. Atawia RT, Bunch KL, Toque HA et al. Mechanisms of obesity-induced metabolic and vascular dysfunctions. Front Bioscience 2019;24:890-934.

41. Wolk R, Berger P, Lennon RJ et al. Plasma leptin and prognosis in patients with established coronary atherosclerosis. J Amer Coll Cardiol 2004:44;1819-1824.

42. Lekakis J, Abraham P, Balbarini A et al. Methods for evaluating endothelial function: a position statement from the European Society of Cardiology Working Group on Peripheral Circulation. Eur J Cardiovasc Prev Rehabil 2011;18:775-89.

43. Blann AD. Plasma von Willebrand factor, thrombosis, and the endothelium: the first 30 years. Thromb Haemost. 2006;95:49-55.

44. Ferroni P, Martini F, Riondino S et al. Soluble P-selectin as a marker of in vivo platelet activation. Clin Chim Acta. 2009;399:88-91.

45. Lim HS, Blann AD, Lip GY. Soluble CD40 ligand, soluble P-selectin, interleukin-6, and tissue factor in diabetes mellitus: relationships to cardiovascular disease and risk factor intervention. Circulation. 2004;109:2524-8.

\section{Tables}

Table 1: Demographic, laboratory, and clinical data 


\begin{tabular}{|c|c|c|c|c|}
\hline & $\begin{array}{l}\text { Diabetes } \\
(n=66)\end{array}$ & $\begin{array}{l}\text { Cardiovascular } \\
\text { disease }(n=76)\end{array}$ & $\begin{array}{l}\text { Both diabetes and } \\
\text { cardiovascular disease } \\
(n=70)\end{array}$ & $\begin{array}{l}P \\
\text { value }\end{array}$ \\
\hline \multicolumn{5}{|l|}{ Demographics } \\
\hline Age (years) & $\begin{array}{l}62.8 \\
(10.3)\end{array}$ & $63.0(10.7)$ & $64.8(8.2)$ & 0.409 \\
\hline $\operatorname{Sex}(M / F)$ & $41 / 25$ & $51 / 25$ & $53 / 17$ & 0.224 \\
\hline \multicolumn{5}{|l|}{ Clinical data } \\
\hline SBP (mm Hg) & $143(18)$ & $136(20)$ & $137(21)$ & 0.064 \\
\hline DBP (mm Hg) & $79(12)$ & $79(13)$ & $73(12)$ & 0.008 \\
\hline $\mathrm{BMI}\left(\mathrm{kg} / \mathrm{m}^{2}\right)$ & $\begin{array}{l}31.4 \\
(6.2)\end{array}$ & $27.0(4.2)$ & $30.3(6.3)$ & $<0.001$ \\
\hline $\begin{array}{l}\text { Coronary artery } \\
\text { disease }\end{array}$ & - & $57,75.0$ & $56,80.0$ & 0.470 \\
\hline $\begin{array}{l}\text { Peripheral artery } \\
\text { disease }\end{array}$ & - & $10,13.1$ & $8,11.4$ & 0.101 \\
\hline $\begin{array}{l}\text { Cerebrovascular } \\
\text { disease }\end{array}$ & - & $15,19.7$ & $6,8.6$ & 0.055 \\
\hline \multicolumn{5}{|l|}{ Laboratory data } \\
\hline $\mathrm{HbA} 1 \mathrm{c}(\mathrm{mmol} / \mathrm{mol})$ & $59(15)$ & $42(3)$ & $64(23)$ & $<0.001$ \\
\hline Creatinine $(\mu \mathrm{mol} / \mathrm{L})$ & $106(45)$ & $88(21)$ & $100(30)$ & 0.006 \\
\hline Estimated GFR & $66(21)$ & $72(15)$ & $67(19)$ & 0.118 \\
\hline Urinary ACR & $\begin{array}{l}4.7[1.1- \\
14.8]\end{array}$ & - & $3.1[1.4-16.0]$ & 0.973 \\
\hline CRP (mg/L) & $\begin{array}{l}3.1[2.5- \\
3.5]\end{array}$ & $3.0[2.6-3.5]$ & $3.0[2.7-3.5]$ & 0.945 \\
\hline \multicolumn{5}{|l|}{ Antithrombotic } \\
\hline \multicolumn{5}{|l|}{ Medications (n, \%) } \\
\hline Anti-platelet & $23,34.8$ & $65,85.6$ & $58,82.9$ & $<0.001$ \\
\hline Anti-coagulant & $6,9.1$ & $8,10.5$ & $5,7.1$ & n.a. \\
\hline Dual therapy & 0 & $1,1.3$ & $5,7.1$ & n.a. \\
\hline Neither therapy & $37,56.1$ & $2,2.6$ & $2,2.9$ & n.a. \\
\hline $\begin{array}{l}\text { Anti-hypertensive } \\
\text { medications (n, \%) }\end{array}$ & & & & \\
\hline
\end{tabular}




\begin{tabular}{|lllll|}
$\begin{array}{l}\text { Calcium channel } \\
\text { blocker }\end{array}$ & $37,56.1$ & $23,30.3$ & $27,38.6$ & 0.007 \\
\hline ACEI/ARB & $42,63.6$ & $55,72.4$ & $57,81.4$ & 0.066 \\
\hline Beta-blocker & $18,27.3$ & $33,25.1$ & $41,58.6$ & 0.001 \\
\hline Diuretic & $32,48.5$ & $16,21.1$ & $35,50.0$ & $<0.001$ \\
\hline $\begin{array}{l}\text { Lipid-lowering } \\
\text { medications (n, \%) }\end{array}$ & & & & \\
\hline Statin & $46,69.7$ & $72,94.7$ & $68,97.1$ & .a. \\
\hline Resin & 0 & $1,1.3$ & $1,1.4$ & \\
\hline $\begin{array}{l}\text { Glucose-regulating } \\
\text { medications (n, \%) }\end{array}$ & & & & 0.001 \\
\hline Metformin & $49,74.2$ & - & $41,58.6$ & 0.053 \\
\hline $\begin{array}{l}\text { Insulin } \\
\text { Sulphonylurea }\end{array}$ & $28,42.4$ & - & $26,37.1$ & 0.529 \\
\hline DPP-4 inhibitor & $13,19.7$ & - & $14,20.0$ & 0.964 \\
\hline
\end{tabular}

SBP: systolic blood pressure. DBP: diastolic blood pressure. BMI: body mass index. GFR: glomerular filtration rate. ACR: albumin to creatinine ratio. CRP: C-reactive protein. ACEI/ARB: angiotensin converting enzyme inhibitor/angiotensin receptor blocker. Data mean (SD), n, \%, or median [interquartile range]. n.a. $=$ not analysable (underpowered).

\section{Table 2: Research indices}




\begin{tabular}{|c|c|c|c|c|}
\hline & $\begin{array}{l}\text { Diabetes } \\
(n=66)\end{array}$ & $\begin{array}{l}\text { Cardiovascular } \\
\text { disease }(n=76)\end{array}$ & $\begin{array}{l}\text { Both diabetes and } \\
\text { cardiovascular disease }(n=70)\end{array}$ & $\begin{array}{l}P \\
\text { value }\end{array}$ \\
\hline \multicolumn{5}{|l|}{$\begin{array}{l}\text { Angiogenesis } \\
\text { markers }\end{array}$} \\
\hline $\begin{array}{l}\text { Angiopoietin-1 } \\
(\mathrm{ng} / \mathrm{mL})\end{array}$ & $\begin{array}{l}3.0[1.6- \\
4.4]\end{array}$ & $2.7[1.8-4.2]$ & $2.7[1.5-4.0]$ & 0.716 \\
\hline $\begin{array}{l}\text { Angiopoietin-2 } \\
(\mathrm{ng} / \mathrm{mL})\end{array}$ & $\begin{array}{l}0.77 \\
{[0.58-} \\
1.62]\end{array}$ & $0.73[0.49-1.16]$ & $0.90[0.62-1.40]$ & 0.124 \\
\hline $\operatorname{VEGF}(\mathrm{pg} / \mathrm{mL})$ & $\begin{array}{l}21[13- \\
36]\end{array}$ & 23 [13-37] & 31 [17-61] & 0.040 \\
\hline Endoglin (ng/mL) & $\begin{array}{l}1.12 \\
{[0.81-} \\
1.67]\end{array}$ & 1.18 [0.84-1.65] & $1.01[0.80-1.46]$ & 0.421 \\
\hline \multicolumn{5}{|l|}{ Metabolic } \\
\hline \multicolumn{5}{|l|}{ Markers } \\
\hline sRAGE (ng/mL) & $\begin{array}{l}1.6[1.2- \\
2.6]\end{array}$ & $1.7[1.4-2.6]$ & $1.7[1.2-2.6]$ & 0.916 \\
\hline Cystatin-C (ng/mL) & $\begin{array}{l}21[16- \\
25]\end{array}$ & 18 [16-22] & 22 [18-27] & 0.004 \\
\hline Leptin (ng/mL) & $\begin{array}{l}1.7[0.8- \\
3.4]\end{array}$ & $1.4[0.7-2.9]$ & $1.9[0.9-3.5]$ & 0.381 \\
\hline Lipocalin (ng/mL) & $\begin{array}{l}57[42- \\
73]\end{array}$ & 67 [39-84] & $64[46-77]$ & 0.310 \\
\hline $\begin{array}{l}\text { Interleukin-8 } \\
(\mathrm{ng} / \mathrm{mL})\end{array}$ & $\begin{array}{l}0.17 \\
(0.03)\end{array}$ & $0.18(0.02)$ & $0.17(0.02)$ & 0.736 \\
\hline \multicolumn{5}{|l|}{$\begin{array}{l}\text { Endothelial and } \\
\text { platelet markers }\end{array}$} \\
\hline vWf (IU/dL) & 109 [22] & 112 [23] & 123 [25] & 0.001 \\
\hline sEsel (ng/mL) & $\begin{array}{l}24[15- \\
29]\end{array}$ & 25 [22-32] & 27 [21-31] & 0.045 \\
\hline $\operatorname{EMPs}\left(\times 10^{3} / \mu \mathrm{L}\right)$ & 30 [7-88] & $32[4-97]$ & 53 [17-112] & 0.042 \\
\hline sPsel (ng/mL) & $\begin{array}{l}20[13- \\
39]\end{array}$ & 15 [13-18] & 18 [15-26] & $<0.001$ \\
\hline PMPs $\left(x 10^{3} / \mu \mathrm{L}\right)$ & $6[1-42]$ & $11[1-55]$ & $9[1-38]$ & 0.603 \\
\hline
\end{tabular}


Data mean (SD) or median [inter-quartile range]. VEGF = vascular endothelial growth factor, SRAGE = soluble receptor for advanced glycation products, $\mathrm{vWf}=$ von Willebrand factor, $\mathrm{sEsel}=$ soluble $\mathrm{E}$ selectin, sPsel = soluble $\mathrm{P}$ selectin, EMPs = endothelial microparticles, PMPs = platelet microparticles. 